\title{
Trace minerals pollution in south indian branded tea, and from the tea waste disposal sites
}

\section{Selvam Ramarajan, Sugumar Susila, Duraisamy Tamilselvi, Muthunarayanan Vasanthy *}

Department of Environmental Biotechnology, School of Environmental Sciences, Bharathidasan University, Tiruchirappalli, India

\section{Article Info}

Received : 05.12.2017 Accepted : 14.05 .2018

\begin{abstract}
We aim to quantify heavy metals in tea powders (packed and used), tea waste disposal sites and in the soil away from the site of disposal and to isolate the bacteria from both the soil sample. Atomic Absorption Spectrometer (AAS) analysis revealed chromium in the samples collected from Thanjavur $(0.12 \mathrm{mg} / \mathrm{kg})$ and Tiruchirappalli $(4.77 \mathrm{mg} / \mathrm{kg})$. The quantity of Copper was between $0.14 \mathrm{mg} / \mathrm{kg}$ and $0.97 \mathrm{mg} / \mathrm{kg}$ Namakkal and Erode samples respectively. We also found trace levels of other heavy metals. The spatial map distribution patterns of selected Physico-chemical parameters like pH, EC, Alkalinity, Total carbon in the disposal sites were presented. Some of the metal-intolerant strains isolated from the disposal sites became resistant. Further investigation would unravel the possible mechanism behind Chromium reduction by the selected isolates.
\end{abstract}

Keywords: Toxic metal, tea powder, AAS, spatial map, chromium, biosorption.

(C) 2018 Federation of Eurasian Soil Science Societies. All rights reserved

\section{Introduction}

Tea from the leaves of the shrub Camellia sinensis is the most preferred consumable beverage worldwide (Fernández-Cáceres et al., 2001). Approximately about 18-20 billion consumers drink tea daily. Despite its medicinal properties, it also contains numerous toxic elements ( $\mathrm{Fe}, \mathrm{Mn}, \mathrm{Cr}, \mathrm{Zn}, \mathrm{Cu}$ ) (TEs) in trace quantity (Shen and Chen, 2008). These TEs are present in domestic and industrial wastewater, dust, vehicular exhaust and industrial emissions etc. that affect agricultural lands and plants (Singh et al., 2010; Muntean et al., 2013). The TEs such as cadmium from fallouts of vehicular exhaust and dust were reported to affect tea plants by getting deposited on the leaves. Other TEs such as Mercury, Lead, Arsenic, Chromium, Iron and Cadmium were also found in tea leaves in trace level, however harmful to humans (Wang et al., 2008; Han et al., 2006; Sadeghi et al., 2011). Studies exist to demonstrate the ROS production along with oxidative stress play a major role in the toxicity and carcinogenicity of metals such as $\mathrm{As}, \mathrm{Cd}, \mathrm{Cr}$ and $\mathrm{Hg}$ (Tchounwou et al., 2001; Tchounwou et al., 2004; Yedjou and Tchounwou, 2006; Yedjou and Tchounwou, 2007). Due to their toxicity these heavy metals were ranked as priority metals that are of great public health significance (Tchounwou et al., 2012). The occurrence of TEs in tea plants is mainly by absorption from nutrient supplementation, growth media, industrial wastes, organic and inorganic fertilizers, and pesticides. These TEs cause delayed flowering, reduced chlorophyll content and shortening the shoot length (Mani et al., 2014). Chromium is reported to be one of the most popular TEs and is found to get added tea mainly from the crush-tear-curl rollers used to prepare tea which usually contain chromium (Seenivasan et al., 2008). No

\footnotetext{
${ }^{*}$ Corresponding author.

Department of Environmental Biotechnology, School of Environmental Sciences, Bharathidasan University, Tiruchirappalli 620 024, India

Tel.: +914312407088

E-mail address: drvasanthy02@gmail.com

e-ISSN: 2147-4249 DOI: 10.18393/ejss.424989
} 
studies were performed hitherto on the estimation of toxic metals in tea powder and tea waste disposal sites, however these types of agro based waste has been used as adsorbents for heavy metal removal (Demirbas, 2008). Hence the present study has been framed with the following objectives.

The objective were to,

(i) analyze TEs in commercially available packed Tea Powder (TP), Used Tea Powder (UTP), soil samples collected from the tea waste disposal site (Soil Contaminated-SC) and the soil samples collected away from the disposal site (Soil Un-Contaminated-SUC).

(ii) Isolate the soil bacteria collected from disposal sites (SC and SUC)

(iii) Evaluate the metal resistance potential of the isolated bacterial strains against chromium and to determine MTC (Maximum Tolerance Concentration) of individual bacterial strains, and

(iv) To determine the physico-chemical characteristics of the soil with spatial map presentation.

\section{Material and Methods}

\section{Sample collection}

The soil samples were collected from various districts of Tamilnadu (South India) such as Chennai, Kanyakumari, Tiruchirappalli, Salem, Namakkal, Thiruvarur, Thanjavur, Pudukkottai, Madurai and Erode (Figure 1). We made a V-shaped cut (15-20 cm depth) and collected smooth side of the soil (1 cm slice) in a clean bucket and mixed well (Figure 2). The tools used for sampling includes shovel, spade and augers (Parker, 2009). The samples were homogenized, air-dried and sieved with a $2 \mathrm{~mm}$ wire mesh before analysis.

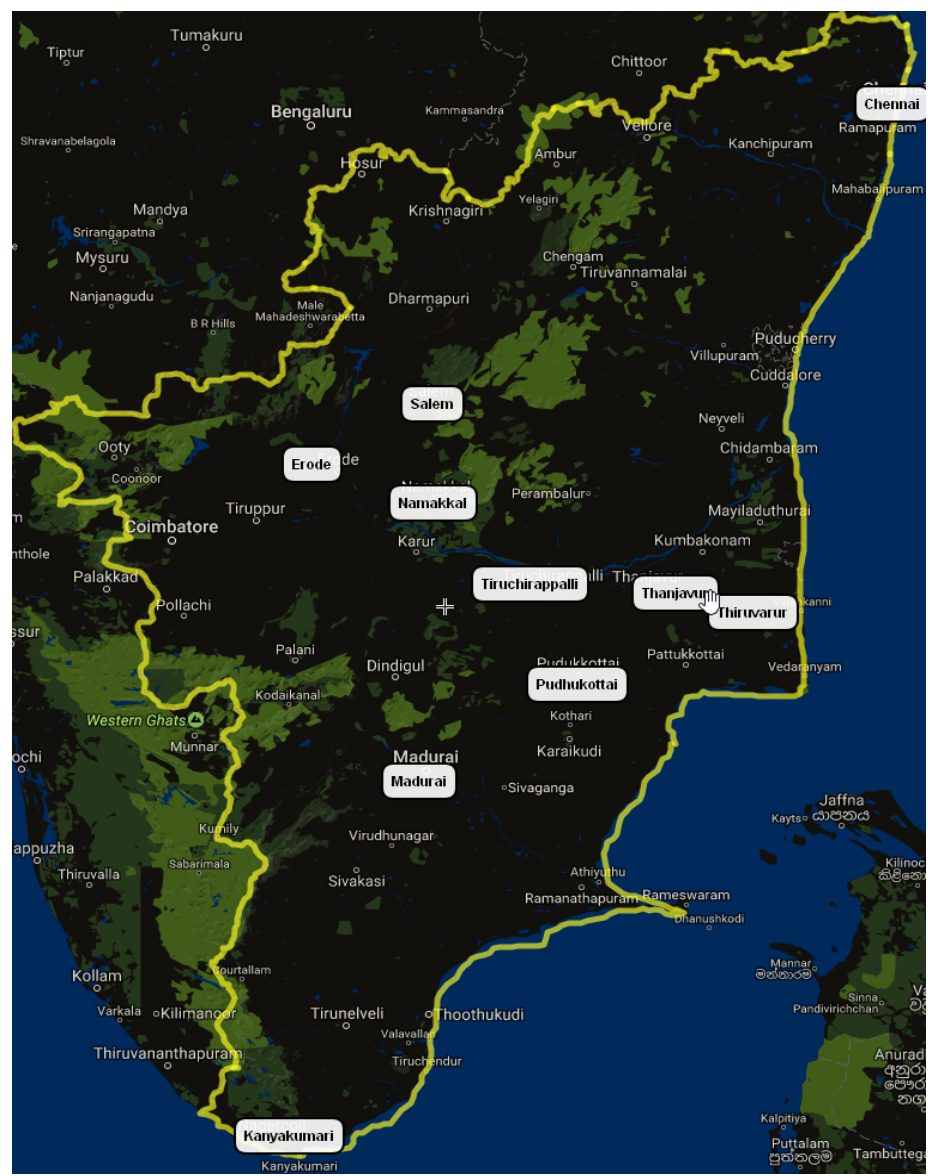

Figure 1. Study area- Sampling sites

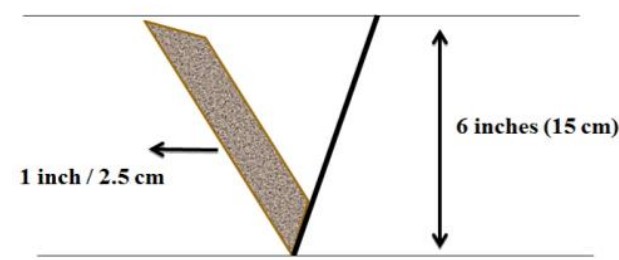

Figure 2. Sample collection method 


\section{Preparation of soil sample for Physico-chemical analysis}

The preparation of soil sample is, $1 \mathrm{~g}$ of soil sample was dissolved in $20 \mathrm{~mL}$ of double distilled water and kept for $30 \mathrm{~min}$ in shaker. After mixing, the sample were filtered and subjected to the analysis of Physicochemical parameters such as $\mathrm{pH}$, electrical conductivity (EC), alkalinity and organic carbon (without water mixing) (APHA, 2005).

\section{$\mathrm{I}=\sqrt{\mathrm{X} 1}=\mathrm{X} 2=\mathrm{X} 3=\mathrm{X} 4=\mathrm{X} 5 / 5$}

Note: This formula represented the spatial distribution of geographical map with weightage data included physicochemical and Heavy metal analysis. (I=Index, $\mathrm{X}=$ Weightage of metals impact)

\section{Quantification of Heavy metals in the samples}

To quantify the heavy metals, $1 \mathrm{~g}$ of TP, UTP and $0.5 \mathrm{~g}$ of SC, SUC were digested using Microwave digester (MDS-6, SINEO Microwave Chemistry Technology Co., Ltd). The operating condition specific for each metals are summarized in Table 2, 3 and 4 (Xin et al., 2010). Samples were analyzed in triplicate using Graphite Furnace Atomic Absorption Spectrophotometer (Thermo Scientific ICE 3000 series, Solar data station (v.11.02)) to quantify $\mathrm{Fe}, \mathrm{Mn}, \mathrm{Cr}, \mathrm{Zn}$, and $\mathrm{Cu}$.

\section{Biosorption studies}

The bacterial strains isolated from disposal sites (SC and SUC) were streaked onto the nutrient agar media supplemented with metal concentrations ranging from 100 to $1000 \mathrm{ppm}$. For biosorption studies, the plates were incubated at $30^{\circ} \mathrm{C}$ for 24 to 72 hours and the isolated bacterial strains were inoculated into $100 \mathrm{~mL}$ of nutrient medium supplemented with glucose (1\%) and urea (1\%) containing different concentrations of $\mathrm{Cr}$ (VI) as $\mathrm{K}_{2} \mathrm{Cr}_{2} \mathrm{O}_{7}(100-500 \mathrm{ppm})$ followed by incubation at $37^{\circ} \mathrm{C}$ for $120 \mathrm{rpm}$ for 24 hours in a mechanical shaker. The samples were centrifuged at 10,000 rpm for $15 \mathrm{~min}$ in a cooling centrifuge (Model: REMI C-24) at $4^{\circ} \mathrm{C}$ and the supernatant was subjected to ultra-sonication and chromium concentration was determined using di-phenyl carbazide reagent in acid solution (APHA, 1998) by measuring the absorbance at $540 \mathrm{~nm}$ in a spectrophotometer (2202- PC, Systronic). Thus Cr (VI)-reduction by the isolated strains was investigated. Samples were analyzed for the reduction of $\mathrm{Cr}(\mathrm{VI})$ at regular intervals.

\section{Results and Discussion}

The physico- chemical parameters such as $\mathrm{pH}, \mathrm{EC}$, alkalinity and total organic carbon were analyzed in used tea powder SC and SUC (Table 1) with representation of corresponding spatial map (Figure 3).

Table 1. Physico-chemical characteristics of tea waste SC and SUC: [Mean \pm SD $(N=3)]$.

\begin{tabular}{|c|c|c|c|c|c|}
\hline $\begin{array}{l}\text { Area of sample } \\
\text { collection }\end{array}$ & $\begin{array}{l}\text { Types } \\
\text { of soil }\end{array}$ & $\mathrm{pH}$ & $\begin{array}{c}\mathrm{EC} \\
(\mu \mathrm{s} / \mathrm{cm})\end{array}$ & $\begin{array}{l}\text { Alkalinity } \\
(\mathrm{mg} / \mathrm{kg})\end{array}$ & $\begin{array}{l}\text { Carbon } \\
\text { (mg/kg) }\end{array}$ \\
\hline \multirow[t]{2}{*}{ Tiruchirappalli } & SC & $5.183 \pm 0.015$ & $0.866 \pm 0.014$ & $33.33 \pm 5.773$ & $5.486 \pm 0.195$ \\
\hline & SUC & $5.896 \pm 1.103$ & $0.789 \pm 0.007$ & $46.66 \pm 15.275$ & $4.286 \pm 0.145$ \\
\hline \multirow[t]{2}{*}{ Salem } & SC & $8.066 \pm 0.055$ & $0.616 \pm 0.007$ & $46.66 \pm 05.773$ & $2.613 \pm 0.208$ \\
\hline & SUC & $7.826 \pm 7.826$ & $0.595 \pm 0.595$ & $46.66 \pm 46.660$ & $2.830 \pm 2.830$ \\
\hline \multirow[t]{2}{*}{ Namakkal } & SC & $7.813 \pm 0.051$ & $0.587 \pm 0.004$ & $80.00 \pm 10.000$ & $1.720 \pm 0.206$ \\
\hline & SUC & $7.523 \pm 0.092$ & $0.491 \pm 0.003$ & $53.33 \pm 05.773$ & $1.923 \pm 0.049$ \\
\hline \multirow[t]{2}{*}{ Chennai } & SC & $7.130 \pm 0.050$ & $0.977 \pm 0.018$ & $73.33 \pm 05.773$ & $1.876 \pm 0.051$ \\
\hline & SUC & $7.156 \pm 0.020$ & $0.818 \pm 0.002$ & $96.66 \pm 5.773$ & $2.946 \pm 0.020$ \\
\hline \multirow{2}{*}{ Thanjavur } & SC & $6.146 \pm 0.404$ & $0.639 \pm 0.005$ & $46.66 \pm 10.000$ & $2.333 \pm 0.055$ \\
\hline & SUC & $7.186 \pm 0.070$ & $0.167 \pm 0.028$ & $76.66 \pm 05.773$ & $2.846 \pm 0.120$ \\
\hline \multirow[t]{2}{*}{ Thiruvarur } & SC & $6.833 \pm 0.404$ & $0.153 \pm 0.005$ & $50.00 \pm 10.000$ & $2.943 \pm 0.055$ \\
\hline & SUC & $7.186 \pm 0.070$ & $0.167 \pm 0.028$ & $76.66 \pm 05.773$ & $2.846 \pm 0.120$ \\
\hline \multirow[t]{2}{*}{ Madurai } & SC & $8.003 \pm 0.060$ & $0.743 \pm 0.022$ & $50.00 \pm 10.000$ & $3.323 \pm 0.222$ \\
\hline & SUC & $7.386 \pm 0.180$ & $0.448 \pm 0.022$ & $70.00 \pm 10.000$ & $1.653 \pm 0.150$ \\
\hline \multirow[t]{2}{*}{ Erode } & SC & $6.560 \pm 0.245$ & $0.754 \pm 0.012$ & $43.33 \pm 05.773$ & $1.676 \pm 0.090$ \\
\hline & SUC & $7.036 \pm 0.572$ & $0.806 \pm 0.032$ & $60.00 \pm 10.000$ & $1.913 \pm 0.120$ \\
\hline \multirow[t]{2}{*}{ Kanyakumari } & SC & $7.363 \pm 0.245$ & $0.169 \pm 0.010$ & $40.00 \pm 10.000$ & $1.800 \pm 0.170$ \\
\hline & SUC & $6.793 \pm 0.410$ & $0.267 \pm 0.219$ & $43.33 \pm 05.773$ & $1.897 \pm 0.068$ \\
\hline \multirow{2}{*}{ Pudukkottai } & SC & $7.403 \pm 0.218$ & $1.000 \pm 0.105$ & $73.34 \pm 11.547$ & $2.423 \pm 0.090$ \\
\hline & SUC & $6.556 \pm 0.196$ & $0.620 \pm 0.404$ & $73.33 \pm 05.773$ & $1.913 \pm 0.058$ \\
\hline
\end{tabular}


Table 2. The acid composition of Microwave digester mixture.

\begin{tabular}{ccccc}
\hline Sample type & Gram $(\mathrm{g})$ & $\mathrm{HNO}_{3}(65 \%)$ & $\mathrm{H}_{2} \mathrm{O}_{2}(\mathrm{~mL})$ & Time (min) \\
\hline TP & 1.0 & $6 \mathrm{~mL}$ & 2.5 & 20 \\
UTP & 1.0 & $6 \mathrm{~mL}$ & 2.5 & 20 \\
SC & 0.5 & $4 \mathrm{~mL}$ & 6 & 30 \\
SUC & 0.5 & $4 \mathrm{~mL}$ & 6 & 30 \\
\hline
\end{tabular}

Table 3. Operating conditions with wavelength for GF-AAS.

\begin{tabular}{llllll}
\hline Elements & $\mathrm{Mn}$ & $\mathrm{Fe}$ & $\mathrm{Cr}$ & $\mathrm{Zn}$ & $\mathrm{Cu}$ \\
\hline Sampling volume & 20 & 20 & 20 & 20 & 20 \\
Wavelength (nm) & 259.4 & 269.4 & 215.9 & 213.2 & 326.7 \\
Lamp current (mA) & 8 & 6 & 10 & 13 & 12 \\
Gas flow (Inner /Outer) & 1.5 & 1.5 & 1.5 & 1.5 & 1.5 \\
Band Pass width & 0.6 & 0.5 & 0.4 & 0.3 & 0.3 \\
\hline
\end{tabular}

Table 4. Atomization temperature-time program

\begin{tabular}{lcccc}
\hline & Temp. ${ }^{\circ} \mathrm{C}$ & Ramp $\left({ }^{\circ} \mathrm{C} \mathrm{s}^{-1}\right)$ & Hold (s) & Purge Argon flow \\
\hline Drying & 110 & 50 & 20 & 2 \\
Pyrolysis I & 600 & 30 & 10 & 2 \\
Pyrolysis II & 800 & 20 & 5 & 2 \\
Atomization & 2075 & - & 3 & 0 \\
Cleaning & 2300 & - & 2 & 2 \\
\hline
\end{tabular}

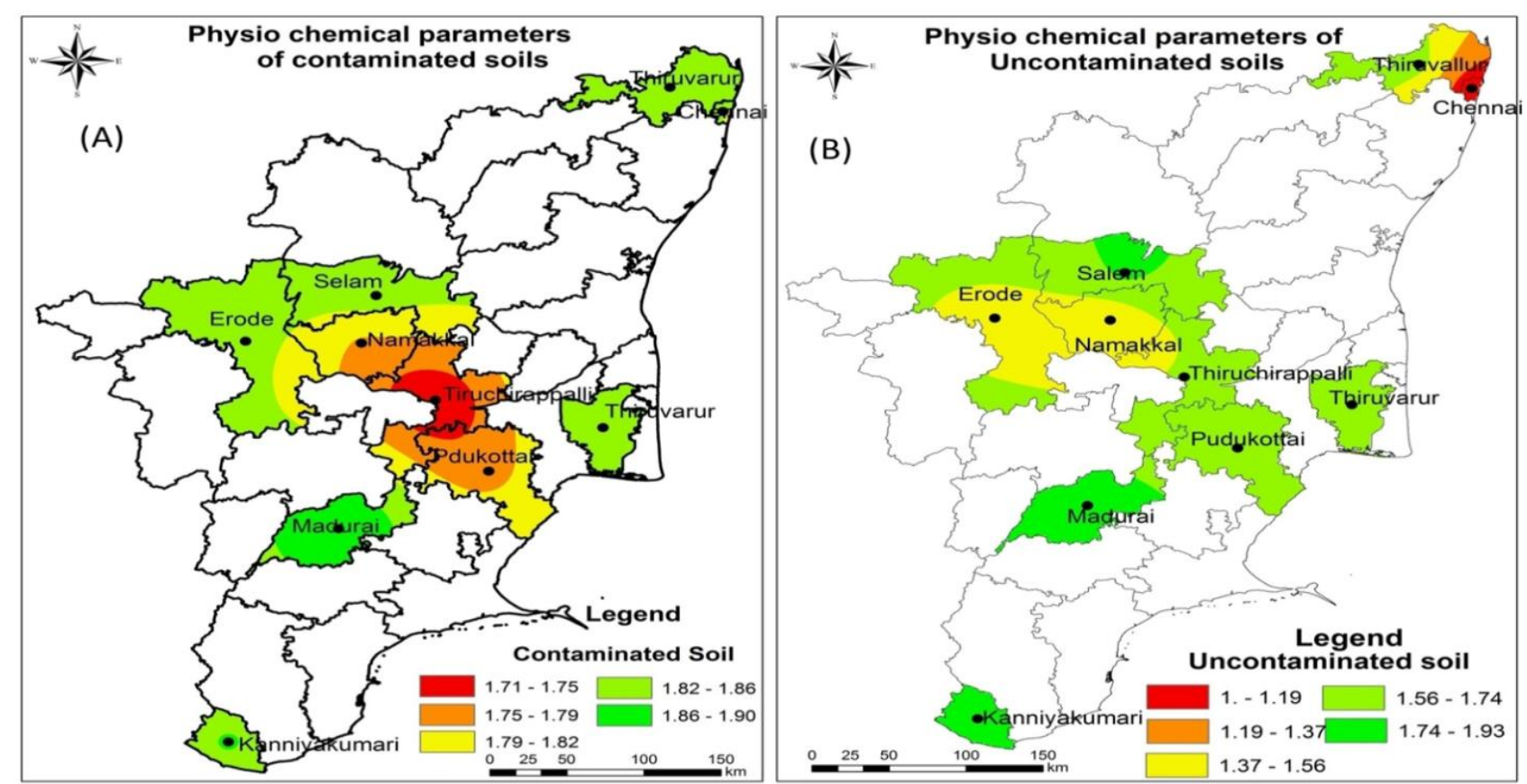

Figure 3. Spatial distribution of monitoring stations across Tamilnadu and this map shows the physicochemical (pH, EC, Alkalinity, Carbon) parameters. The picture named as (A). SC (B). SUC

The concentration of TEs from SC and SUC was determined. The quantity of Fe was $1.01 \mathrm{ppm}$ in the samples collected at Salem and Thanjavur samples contained $13.27 \mathrm{ppm}$, which was the maximum in SC and 3.20 ppm in SUC. Zn was found to be in the range of $0.22 \mathrm{ppm}$ to $3.29 \mathrm{ppm}$ in SC, and the highest quantity was in Madurai and Namakkal samples and $0.85 \mathrm{ppm}$ in SUC. The minimum concentration of $\mathrm{Cr}$ was $0.12 \mathrm{ppm}$, and as high as $4.77 \mathrm{ppm}$ in Tiruchirappalli (SC) samples and $4.07 \mathrm{ppm}$ in SUC. The concentration of Cu in SC was less $(0.15 \mathrm{ppm})$ in Namakkal samples and it was higher in Chennai samples (1.386 ppm). The concentration of $\mathrm{Cu}$ in SUC was about $1.046 \mathrm{ppm}$ in samples collected from Kanyakumari and it was $0.076 \mathrm{ppm}$ in SUC collected from Tiruchirappalli. The least quantity of $\mathrm{Mn}(0.56 \mathrm{ppm})$ was in Namakkal samples, whereas the highest quantity (14.67 ppm) was present in Tiruchirappalli (SC) samples and $12.48 \mathrm{ppm}$ in SUC. Further, the changes in the concentration of all heavy metals varied significantly between different districts (Figure $4)$. 

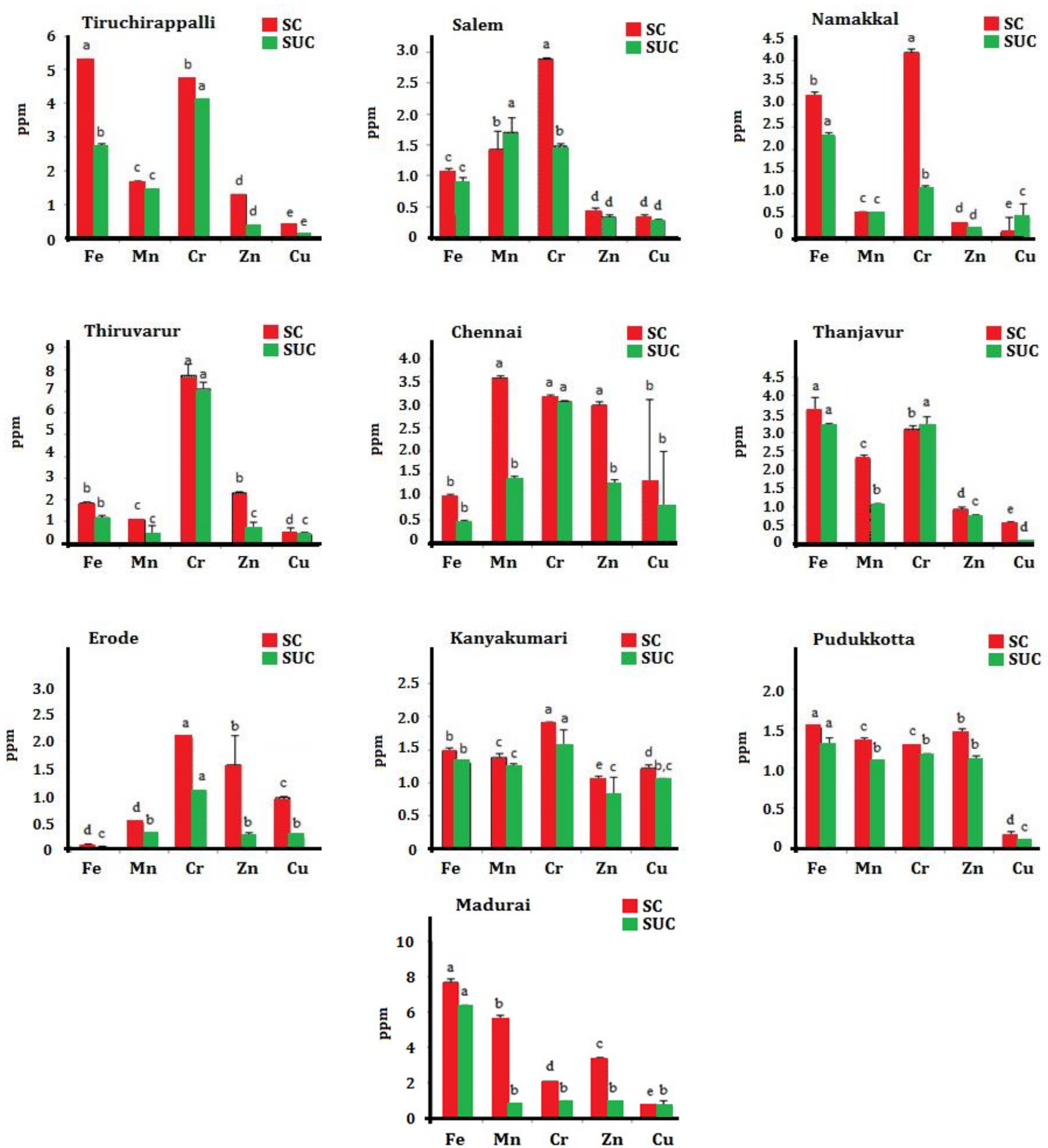

Figure 4. Changes of the heavy metals ( $\mathrm{Fe}, \mathrm{Mn}, \mathrm{Cr}, \mathrm{Zn}, \mathrm{Cu}$ ) concentration in soil contaminated (SC) and soil uncontaminated (SUC) using Atomic adsorption spectrophotometer values were expressed and Mean $\pm \mathrm{SD}(\mathrm{N}=3)$. Bar with different alphabets represents they are significantly different from each other and those with same alphabets have insignificant changes $(\mathrm{P}<0.05)$.

The presence of TEs in the soil samples and different tea powder samples was further represented as spatial maps. The color range (TEs-SC) of $1.34-1.48$ indicated the areas with maximum contamination, followed by 1.48-1.62, which indicated higher contamination. The range of 1.62-1.76 represented moderate contamination, 1.76-1.90 indicated low level of contamination, and 1.90-2.04 revealed the least contamination. The spatial map of SUC showed that the range of TEs 1.48-1.58 exhibited highest contamination followed by $1.58-1.69$ that indicated higher contamination. Subsequent moderate and lower contamination were indicated by the range of 1.69-1.79 and 1.79-1.89, respectively. The lowest level of contamination falls in the color range of $1.89-2.0$ (Figure 5). 


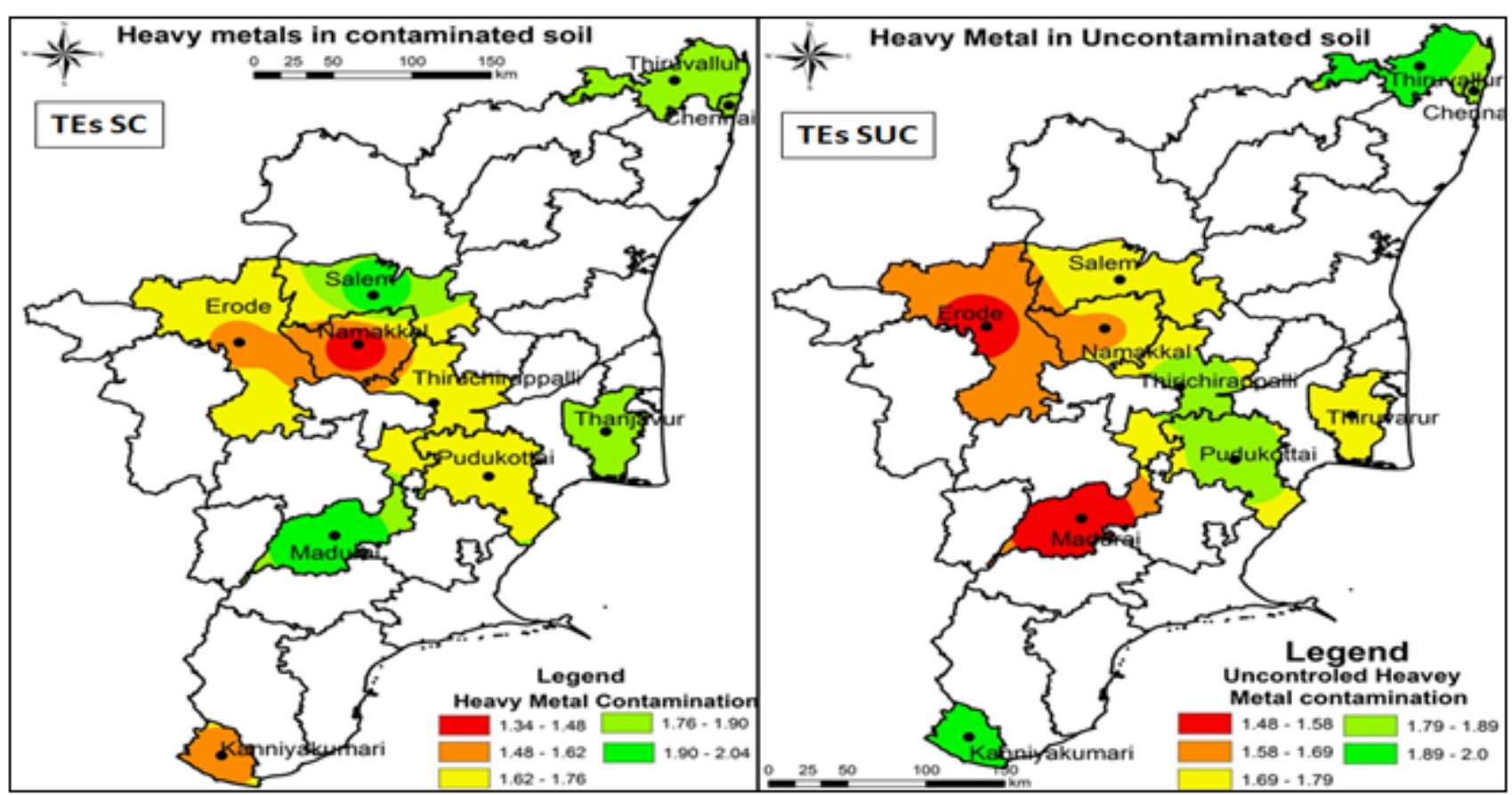

Figure 5. Spatial distribution and concentration of heavy metals in the study area TEs-SC and TEs-SUC.

TEs content was also analyzed in packed and used-tea powders. The concentration of Fe was $0.0011 \mathrm{ppm}$ in Brand $\mathrm{x} 3$ as the minimum and the maximum was about found as $0.0128 \mathrm{ppm}$ in Brand $\mathrm{x} 7$. Zn concentration was $0.0138 \mathrm{ppm}$ in Brand $\mathrm{x} 4$ and in Brand $\mathrm{x} 6$ it was $0.0447 \mathrm{ppm}$. Cr was found at minimum concentration $(0.0348 \mathrm{ppm})$ in Brand $\mathrm{x} 7$ and the maximum $(0.0742 \mathrm{ppm})$ was found in in Brand $\mathrm{x} 1$. Cu in Brand $\mathrm{x} 5$ was $0.0189 \mathrm{ppm}$ and in Brand $\mathrm{x} 1$ it was $0.0448 \mathrm{ppm}$. Mn content was $0.56 \mathrm{ppm}$, and $0.067 \mathrm{ppm}$ in Brand $\mathrm{x} 6$ and Brand x7, respectively (Figure 6).
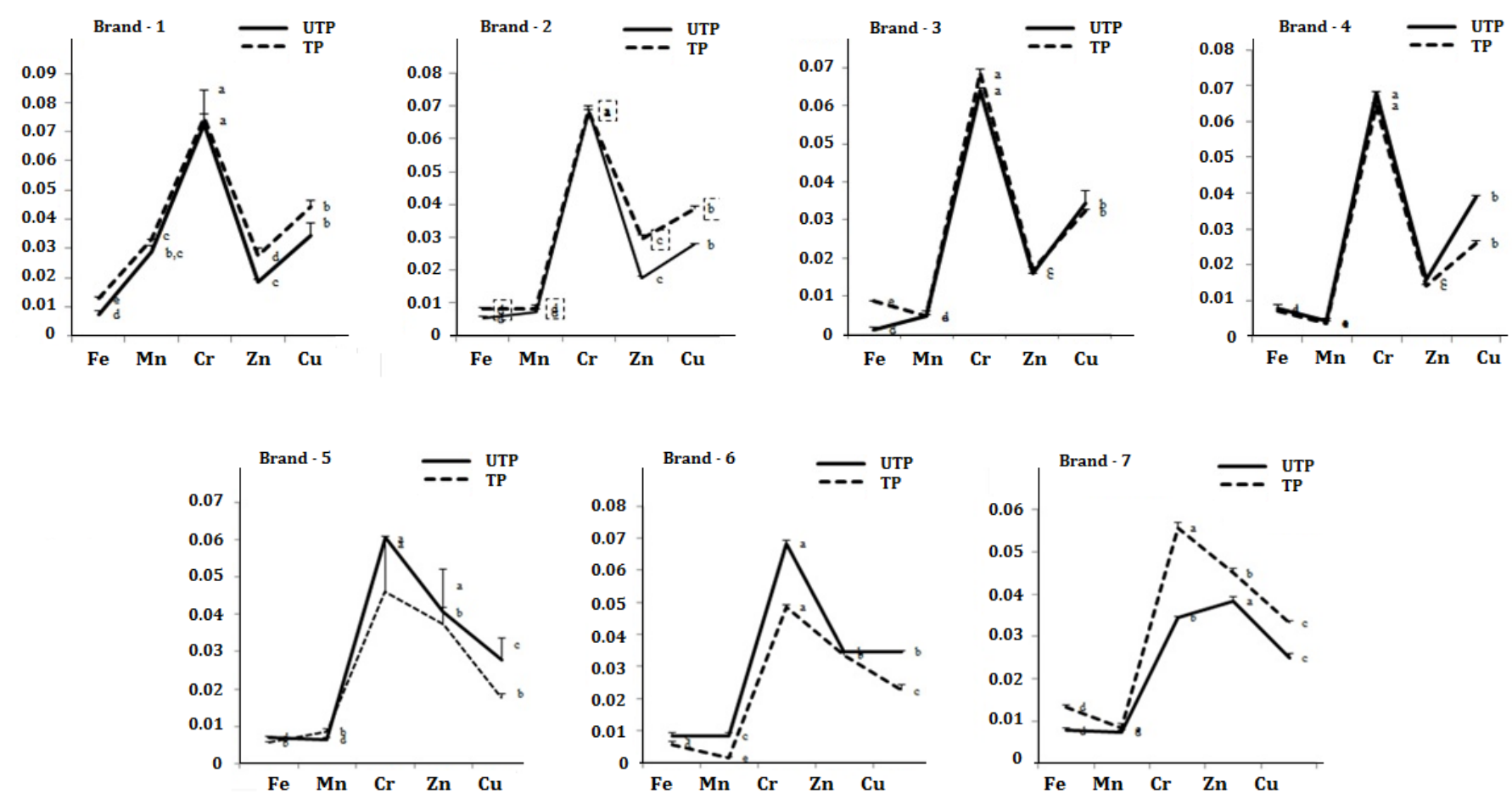

Figure 6. Changes in the TEs (Fe, Mn, $\mathrm{Cr}, \mathrm{Zn}, \mathrm{Cu}$ ) concentration in Tea Powder (TP) and Used Tea Powder (UTP) using Atomic Adsorption Spectrophotometer. Values were expressed as Mean $\pm \mathrm{SD}(\mathrm{N}=3)$ Bar with different alphabets represents they are significantly different from each other and those with same alphabets have insignificant changes $(\mathrm{P} \leq 0.05)$ and the unit of TEs concentration is expressed as ppm.

The MTCs (Maximum tolerable concentration) of the bacterial strains present in various natural habitats such as soil, water, sediments and sewage amended soil have been studied (Abbas and Edwards, 1989). The 
majority of microbes were found to possess two types of uptake mechanisms to reduce the cations and anions. First one is fast, unspecific, constitutively expressed and obsessed by the chemi osmotic gradient across the cytoplasm covering of bacteria. The second one is inducible, possesses high substrate specificity and is slower, repeatedly uses ATP hydrolysis as the power supply and is only produced by the cell in times of need and under special metabolic conditions. Higher amount of essential and nonessential metals can affect the cell membranes; modify enzyme specificity; interrupt cellular functions; and damage the structure of DNA and impose oxidative stress on microbes too (Bruins et al., 2000). In this paper, the metal tolerant microbial strains were randomly selected for their level of resistance against $\mathrm{Cr}$ (VI) concentration. From the MTC analysis, a significant difference in the resistance levels of the bacterial strains isolated from both SC and SUC was noticed (Table 5). The MTC of all isolates Bacillus sp (S1), Bacillus megaterium (S2) (isolates collected from SC), (S3) and Pasteurella haemolytica (S4) (isolates from SUC) was $700 \mathrm{ppm}$. Altogether, all the isolates exhibited similar, tolerance against chromium. The reduction level was $76 \%$ in 100 ppm by strain $1,50.01 \%$ and $69.30 \%$ in 300 ppm by strain S5, and $44.70 \%$ in $400 \mathrm{ppm}$ and $86.04 \% 500 \mathrm{ppm}$ by strain S3 (Figure 7).

Table 5 . Cr tolerance of the isolated bacterial strains.

\begin{tabular}{ccccccccccc}
\hline \multirow{2}{*}{$\begin{array}{c}\text { Isolated } \\
\text { strains }\end{array}$} & \multicolumn{8}{c}{ Activity of isolated bacteria in different concentration (ppm) of Cr(VI) } \\
\cline { 2 - 12 } & 100 & 200 & 300 & 400 & 500 & 600 & 700 & 800 & 900 & 1000 \\
\hline S1 & $\mathrm{R}$ & $\mathrm{R}$ & $\mathrm{R}$ & $\mathrm{R}$ & $\mathrm{R}$ & $\mathrm{R}$ & $\mathrm{R}$ & $\mathrm{S}$ & $\mathrm{A}$ & $\mathrm{A}$ \\
$\mathrm{S} 2$ & $\mathrm{R}$ & $\mathrm{R}$ & $\mathrm{R}$ & $\mathrm{R}$ & $\mathrm{R}$ & $\mathrm{R}$ & $\mathrm{S}$ & $\mathrm{A}$ & $\mathrm{A}$ & $\mathrm{A}$ \\
$\mathrm{S} 3$ & $\mathrm{R}$ & $\mathrm{R}$ & $\mathrm{R}$ & $\mathrm{R}$ & $\mathrm{R}$ & $\mathrm{R}$ & $\mathrm{S}$ & $\mathrm{A}$ & $\mathrm{A}$ & $\mathrm{A}$ \\
$\mathrm{S} 4$ & $\mathrm{R}$ & $\mathrm{R}$ & $\mathrm{R}$ & $\mathrm{R}$ & $\mathrm{R}$ & $\mathrm{R}$ & $\mathrm{S}$ & $\mathrm{A}$ & $\mathrm{A}$ & $\mathrm{A}$ \\
\hline
\end{tabular}

*R- Resistance; A- Absence of growth; S- Sensitive

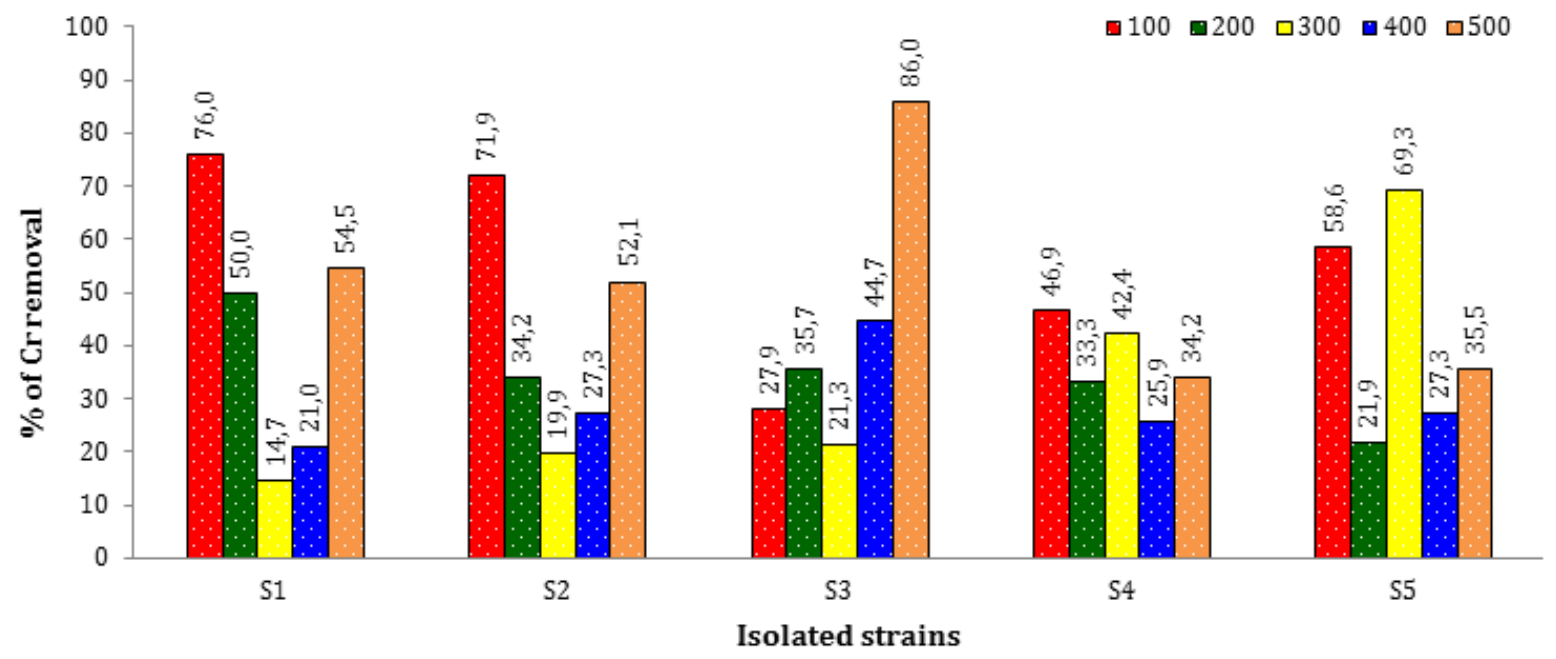

*(S1-S4 refers to the isolated bacterial strains).

Figure 7. Cr reduction by isolated bacterial strains

Already reports exist to prove that the metal biosorption is a two-step process where the functional groups of the metal ions (phosphate, hydroxyl, carboxyl, amino, sulphide, sulphur group, etc.) gets adsorbed to the surface of cells by interaction. However, reports also suggest that TEs can also bind on the surface, which can be eventually eluted by other ions present in chelating agent or acid. Hence this work on identification and quantification of the metal ions in the soil samples is a need of the hour. Further work is needed to understand the mechanism of Biosorption of the metal ions by the autochthonous organisms present in the contaminated areas. Similarly, biosorption referring to the penetration of metal ions into the cell membrane has been already reported (Veglio and Beolchini, 1997; Madrid and Cámara, 1997). Studies exist to understand the biosorption of Cr (VI) and Fe (III) by Streptococcus equisimilis, S. cerevisiae and Aspergillus niger too (Goyal et al., 2003).

\section{Conclusion}

The heavy metal namely, Cr was present in higher quantities of TEs in used tea powder, which was about $0.0742 \mathrm{ppm}$. This data gives a clear understanding that certain quantity of heavy metal added to the soil and the soil had appreciable quantity of native heavy metals already; this may pose a threat to the environment 
and disturb the normal flora present in the disposal site. Further investigation is needed to explore the possible mechanism behind chromium reduction by the selected strains. This study thus focuses on some branded tea, tea waste and disposal site as sources of heavy metal contamination and recommends that the disposal of such used tea waste must not be done in pristine environment so as to conserve the same.

\section{Acknowledgement}

The authors acknowledge the financial support provided by Department of science and Technology (DST), New Delhi, India, towards the sanction of Major Research Project. The authors acknowledge the DST-FIST, DST-INSPIRE, UGC NON- SAP, MOEFCC and UGC-SAP, New Delhi, for the financial support extended to the department.

\section{References}

Abbas, A., Edwards, C., 1989. Effects of metals on a range of Streptomyces species. Applied and Environmental Microbiology 55(8): 2030-2035.

APHA, 2005. Standard methods for the examination of water and wastewater (Vol. 2). American Public Health Association, Washington, USA.

Bruins, M.R., Kapil, S., Oehme, F.W., 2000. Microbial resistance to metals in the environment. Ecotoxicology and Environmental Safety 45(3): 198-207.

Demirbas, A., 2008. Heavy metal adsorption onto agro-based waste materials: A review. Journal of Hazardous Materials 157(2-3): 220-229.

Fernández-Cáceres, P.L., Martín, M.J., Pablos, F., González, A.G., 2001. Differentiation of tea (Camellia sinensis) varieties and their geographical origin according to their metal content. Journal of Agricultural and Food Chemistry 49(10): 4775-4779.

Goyal, N., Jain, S.C., Banerjee, U.C., 2003. Comparative studies on the microbial adsorption of heavy metals. Advances in Environmental Research 7(2): 311-319.

Han, W.Y., Zhao, F.J., Shi, Y.Z., Ma, L.F., Ruan, J.Y., 2006. Scale and causes of lead contamination in Chinese tea. Environmental Pollution 139(1): 125-132.

Madrid, Y.i Cámara, C., 1997. Biological substrates for metal preconcentration and speciation. TrAC Trends in Analytical Chemistry 16(1): 36-44.

Mani, D., Kumar, C., 2014. Biotechnological advances in bioremediation of heavy metals contaminated ecosystems: an overview with special reference to phytoremediation. International Journal of Environmental Science and Technology 11(3): 843-872.

Muntean, N., Muntean, E., Creta, C., Duda, M., 2013. Heavy metals in some commercial herbal teas. ProEnvironment 6: 591-594.

Parker, R., 2009. Plant \& Soil Science: Fundamentals \& Applications. Delmar Cengage Learning, New York, USA. 779p.

Sadeghi, O., Tavassoli, N., Amini, M.M., Ebrahimzadeh, H., Daei, N., 2011. Pyridine-functionalized mesoporous silica as an adsorbent material for the determination of nickel and lead in vegetables grown in close proximity by electrothermal atomic adsorption spectroscopy. Food Chemistry 127(1): 364-368.

Seenivasan, S., Manikandan, N., Muraleedharan, N.N., Selvasundaram, R., 2008. Heavy metal content of black teas from south India. Food Control 19(8): 746-749.

Shen, F.M., Chen, H.W., 2008. Element composition of tea leaves and tea infusions and its impact on health. Bulletin of Environmental Contamination and Toxicology 80(3): 300-304.

Singh, A., Sharma, R.K., Agrawal, M., Marshall, F.M., 2010. Risk assessment of heavy metal toxicity through contaminated vegetables from waste water irrigated area of Varanasi, India. Tropical Ecology 51(2): 375-387.

Tchounwou, P.B., Centeno, J.A., Patlolla, A.K., 2004. Arsenic toxicity, mutagenesis, and carcinogenesis-a health risk assessment and management approach. Molecular and Cellular Biochemistry 255(1-2): 47-55.

Tchounwou, P.B., Yedjou, C.G., Patlolla, A.K., Sutton, D.J., 2012. Heavy metal toxicity and the environment. In: Molecular, clinical and environmental toxicology, Volume 3 Environmental Toxicology. Luch, A. (Ed.). Springer, New York, USA. pp. 133-164.

Veglio, F., Beolchini, F., 1997. Removal of metals by biosorption: a review. Hydrometallurgy 44(3): 301-316.

Wang, X.P., Ma, Y.J., Xu, Y.C., 2008. Studies on contents of arsenic, selenium, mercury and bismuth in tea samples collected from different regions by atomic fluorescence spectrometry. Guang pu xue yu guang pu fen xi=Guang pu 28(7): 1653-1657. [in Chinese]

Xin, J., Huang, B., Yang, Z., Yuan, J., Dai, H., Qiu, Q., 2010. Responses of different water spinach cultivars and their hybrid to $\mathrm{Cd}, \mathrm{Pb}$ and $\mathrm{Cd}-\mathrm{Pb}$ exposures. Journal of Hazardous Materials 175(1): 468-476.

Yedjou, C.G. and Tchounwou, P.B., 2006. Oxidative stress in human leukemia (HL-60), human liver carcinoma (HepG2), and human (Jurkat-T) cells exposed to arsenic trioxide. Proceedings of the 9th International Symposium on Metal Ions in Biology and Medicine Held. Lisboa, Portugal. 21-24 May 2006. pp. 298.

Yedjou, C.G., Tchounwou, P.B., 2007. In-vitro cytotoxic and genotoxic effects of arsenic trioxide on human leukemia (HL60) cells using the MTT and alkaline single cell gel electrophoresis (Comet) assays. Molecular and Cellular Biochemistry 301(1-2): 123-130. 